\title{
KEARIFAN LOKAL MENUJU PENGUATAN KARAKTER SOSIAL: SUATU TANTANGAN DARI KEMAJEMUKAN BUDAYA DI SUMATERA BARAT ${ }^{1}$
}

\author{
Nursyirwan Effendi ${ }^{2}$
}

\begin{abstract}
This paper introduces a general understanding of local wisdom that may strengthen social identity to sustain social integrity in a plural society. Local wisdom may become a buzzword in modern societies where social and cultural diversity challenges the existence of society as a whole. West Sumatra Province deals with kind of social development where people from different ethnic groups background in Indonesia have already settled among local people in the provice. The Minangkabau, as people of origin and already enjoyed their majority, cannot avoid the pluralistic social interactions taking place in their own home land. Is this current social development sensitive? How local wisdom may play a role of avoiding social sensistivity?.
\end{abstract}

Results of this study show that plurality is unavoidablesocial consequences among Minangkabau people today and local wisdom become richer in terms of variations as before due to each community of different ethnic groups bringing it with them as long as living in the area of Minangkabau people. Hence the local wisdom may vary socal characteristics among communities. Main conclusion is local wisdom may play an important role of providing an alternative way of avoiding crisis of social integration in the context of west Sumatra province.

Keywords: Plurality, Cultural diversity, Local wisdom, Social integration, Adat

A. Pendahuluan

umatera Barat merupakan salah
satu dari 34 provinsi di Indonesia
yang
memiliki kemajemukan budaya. Hal ini ditandai dengan beragamnya identitas sosial, variasi suku bangsa yang bermukim di daerah ini dan gaya hidup masyarakat yang berorientasi global. Pendapat ini dapat dikatakan sebagai representasi karakter masyarakat Indonesia yang bersifat sangat variatif mulai dari homogen, heterogen, majemuk sampai dengan multikultural. Sifat homogen biasanya tergambarkan dalam pola kehidupan di masyarakat desa melalui penandaan aspek kekerabatan, kesukuan dan asal usul nenek moyang yang membentuk jalinan sosial yang erat dari generasi ke generasi.
Sifat homogen ini dipersatukan dalam suatu entitas sosial setingkat desa yang sangat lokal sifatnya, seperti desa di Aceh disebut gampong, desa di Batak disebut huta, desa di Minangkabau disebut nagari, desa di Palembang (daerah Lahat) disebut marga, di Bali disebut banjar, di Minahasa disebut puak, atau juga kawanua, di suku dayak Panyadu, Kalimantan Barat, desa disebut bandong, dsb. Sifat homogen masyarakat desa terutama dikuatkan dengan modal sosial berbasis genealogis. Biasanya pada level suku dan kekerabatan, identitas sosial mudah dikenali dari perwujudan perilaku dan nilai budaya yang dianut.

Bergerak ke tingkat yang lebih luas, setaraf kabupaten dan kota, maka karakter masyarakat lebih bersifat

\footnotetext{
${ }^{1}$ Tulisan ini merupakan sebuah makalah yang pernah disampaikan pada acara Workshop Internalisasi Nilai Budaya Pada Komunitas Remaja yang diselenggarakan oleh Direktorat Internalisasi Nilai dan Diplomasi Budaya Ditjen Kebudayaan Kemendikbud RI bekerjasama dengan Balai Pelestarian Nilai Budaya (BPNB) Padang di The Hill Hotel, Bukittinggi pada tanggal 15-17 Desember 2013

2 Penulis adalah Dosen Tetap Jurusan Antropologi FISIP Universitas Andalas, Padang
} 
heterogen. Tidak dapat dielakkan lagi bahwa komposisi masyarakat yang bervariasi pada level ini dilihat dari perbedaan asal usul, strata sosial ekonomi dan pendidikan, penguasaan property dan sebagainya, menyumbang gagasan kepada tidak dapat dinyatakannya secara sederhana gambaran utama karakter sosialnya. Sifat masyarakat yang heterogen memberikan ruang bagi terciptanya perbedaan kepentingan, orientasi nilai dan gaya hidup yang semakin diverjen (terbelah). Tantangan terbesar dalam masyarakat yang heterogen setingkat kota atau kabupaten adalah, pada satu sisi, konflik sosial, dan, di sisi lain, tuntutan terhadap terwujudnya integrasi sosial. Perbedaan suku bangsa, ras dan agama adalah isu yang acapkali diketengahkan dalam berbagai diskusi tentang asal penyebab terjadinya konflik. Dalam konteks Indonesia, konflik yang terjadi pada 3 tahun terakhir (sejak tahun 2010) adalah 351 peristiwa konflik. Baik konflik yang bernuansa SARA, bentrokan warga dengan organisasi kemasyarakatan, aksi kekerasan unjuk rasa menolak kenaikan bahan bakar minyak, bentrokan antar massa pendukung calon kepala daerah dan aksi massa terkait sengketa pertanahan. ${ }^{1}$ Konflik-konflik besar pernah mencabik integrasi sosial bangsa yang luar biasa memprihatinkan, semisal kerusuhan Ambon tahun 1999.

Di tingkat yang lebih luas yaitu negara, karakter masyarakat yang majemuk sudah menjadi fakta umum. Hal ini didukung oleh keanekaragaman suku bangsa yang menjadi pembentuk keanekaragaman kebudayaan dari satu komunitas di suatu daerah kepada komunitas di daerah lain. Keanekaragaman ini terbentang gambarannya dari Sabang sampai Merauke. Secara sosiologis, masyarakat majemuk adalah tipikal resmi wajah masyarakat Indonesia dan secara ras telah menentukan wajah keseluruhan keanekaragaman tersebut. Secara etimologis, kata kemajemukan budaya (cultural pluralism) lebih tepat dan sering

${ }^{1}$ (Data Kemendagri dalam rapat kooordinasi nasional Komunitas Intelijen Daerah (Kominda) tahun 2013 di Jakarta). dipergunakan dalam kajian masyarakat majemuk di seluruh dunia. Istilah ini mengandung pengertian bahwa keanekaragam budaya diwakilkan oleh keberadaan suku bangsa yang berbeda dan kelompok minoritas lainnya yang hidup berdampingan dalam mempertahankan identitas masing-masing dalam suatu masyarakat (lihat Theodorson dan Theodorson 1969: 94). Pandangan kemajemukan budaya lebih menekankan kepada upaya membangun terus menerus tata kehidupan yang harmonis dan saling pengertian dari berbagai komunitas daripada upaya membangun asimilasi (pembauran) sosial. Eksistensi masyarakat majemuk seringkali menyandar kepada sistem nilai dan norma budaya dari komunitas yang dominan. Dengan kata lain, terdapat komunitas yang dianggap mayoritas secara kuantitas dan berdasarkan pemilikan kekuasaan. Bersamaan dengan itu terdapat komunitas yang tergolong minoritas, sehingga dalam kemajemukannya, kelompok minoritas ini menunjang kuat perbedaan etnik, kekhususan ekologi dan ketergantungan ekonomi antar komunitas (Kottak, 2006: 303).

Di tingkat yang lebih luas, setingkat bangsa dan negara, istilah masyarakat multikultural mengacu kepada pemahaham tentang eksistensi keanekaragaman budaya dalam suatu negara, dimana keanekaragamannya ini tidak dapat dihindari, namun juga diharapkan hidup terus berdampingan satu dengan lainnya. Dalam masyarakat multikultural, komunitas yang mayoritas maupun minoritas tidak diarahkan untuk berasimilasi, atau terjadinya pembauran dari budaya minoritas ke dalam budaya mayoritas. Upaya mempertahankan tradisi budaya dari masing-masing komunitas yang berbedalah yang sangat diperhatikan, sehingga keanekaragaman tetap terjaga dibawah kesadaran dan sifat saling menghargai terhadap perbedaan tradisi budaya etnik yang dijalankan oleh masing-masing komunitas. Pandangan multikulturalisme menekankan kepada interaksi dari berbagai kelompok etnik dan kontribusi mereka kepada keanekaragaman budaya dalam suatu negara. Kelompk etnik tersebut diarahkan untu saling menawarkan tradisi budaya 
masing-masing dan saling belajar untuk hidup bersama dalam segala bentuk perbedaannya.

Faktanya, karakter masyarakat di atas dalam konteks negara Indonesia dapat ditemui dan dipahami di berbagai tipe masyarakat, mulai dari desa sampai ke kota. Namun, realitas sosial di Indonesia masih belum menampakkan implementasi tentang kemajemukan di dalam tataran pandangan multikulturalisme yang dapat menjamin adanya jaminan integrasi sosial. Kenapa kemajemukan yang sudah niscaya berlangsung dalam masyarakat Indonesia justru menjadi isu sensitif terhadap harmoni sosial? Apakah kearifan lokal dapat diambil sebagai unsur atau karakter budaya guna mempertahankan keutuhan/integrasi sosial?

\section{B. Konteks Kajian}

U ntuk kepentingan tulisan ini, persoalan kemajemukan masyara kat dicermati pada konteks provinsi Sumatera Barat. Dewasa ini, secara tipikal, masyarakat di provinsi Sumatera Barat bersifat majemuk yang mengacu kepada fakta keberadaan budaya dominan (mayoritas) dan budaya sub dominan (minoritas). Jumlah penduduk sampai data bulan Maret 2013 adalah 5.617.977 jiwa (data KPU Sumbar 2013), data BPS berdasarkan hasil sensus tahun 2010 sebanyak 4.846.909 jiwa. Dapat dikatakan bahwa dari jumlah penduduk tersebut, lebih dari $80 \%$ penduduk yang bermukim di provinsi ini berasal dari suku bangsa Minangkabau, sisanya berdomisili sejumlah suku bangsa yang tergolong minoritas yaitu (yang terbesar) suku bangsa Mentawai, kemudian suku-suku bangsa Cina, Nias, Jawa, Sunda, Batak, Aceh, Palembang, Lampung, Makassar, Maluku dan Papua. ${ }^{2}$ Secara sosiologis, kemajemukan budaya telah tergambar dalam gaya hidup sosial di Sumatera Barat, sehingga tantangan untuk membangun harmoni sosial menjadi logis.

\footnotetext{
${ }^{2}$ Belum didapat secara pasti hasil sensus tahun 2010 dan data sampai tahun 2013, tentang jumlah pasti dari masing-masing penduduk yang berasal dari suku-suku bangsa minoritas tersebut.
}

Cara-cara hidup yang menghargai perbedaan tradisi suku bangsa dari masing-masing suku bangsa yang berdomisili di wilayah Sumatera Barat sangat penting untuk diciptakan. Konsekuensi logis dari ni adalah paradigma multikulturalisme sangat penting untuk diimplementasi didalam membangun pola kehidupan yang saling menghargai dari keberadaan berbagai suku bangsa di provinsi Sumatera Barat. Berdasarkan asumsi sosiologis, maka karakter sosial mayoritas provinsi Sumatera Barat diwakili oleh budaya suku bangsa Minangkabau, dan selajutnya secara berbeda diwakili oleh karakter budaya suku bangsa Mentawai, dan kemudian karakter-karakter komunitas dari suku-suku bangsa lain yang ada di wilayah ini, seperti Jawa, Sunda, Batak dll. Berbasis kepada realitas sosial tersebut, pemikiran untuk memahami karakter masyarakat di provinsi ini sangat dibutuhkan.

Konsep yang dipakai untuk menggambarkan karakter masyarakat Sumatera Barat adalah karakter masyarakat yang majemuk. Argumentasinya adalah (1) meskipun sejumlah suku bangsa di Indonesia dapat ditemukan di wilayah provinsi Sumatera Barat, namun secara faktual, interaksi antar budaya dalam masyarakat masih menunjukkan strata mayoritas berhadapan dengan strata sosial yang minoritas; (2) dalam gaya hidup, budaya suku-suku bangsa minoritas belum mampu membangun variasi perilaku budaya yang signifikan dalam kesatuan sosial masyarakat provinsi Sumatera Barat; (3) secara kultural, masyarakat mayoritas Minangkabau di provinsi ini, masih terlalu kuat untuk mempertahankan keberadaan nilai budaya yang dominan dan berbasis kepada suku bangsa Minangkabau; (4) secara politis pemerintahan, pemerintah provinsi Sumatera Barat masih mempertahankan orientasi pengembangan pembangunan untuk masyarakat yang berbasis Minangkabau, misalnya sebagian besar memakai sebutan komunitas adat dengan nama Nagari, sebagai sistem pemerintahan terdepan/terendah dalam masyarakat Sumatera Barat. 
C. Temuan Umum

1. Kemajemukan Budaya dan Konsekuensi Sosial

$\mathrm{P}$ ada pendahuluan di atas, penulis telah menunjukkan fakta sosial budaya bahwa di Sumatera Barat kehidupan masyarakat memiliki variasi budaya dan sosial menurut identitas sukusuku bangsa yang berdomisili di wilayah provinsi ini. Selain itu, interakasi sosial antar individu dan antar kelompok di provinsi ini lebih menggambarkan hubungan sosial dari kelompok mayoritas dan minoritas, atau antara orang Minangkabau dan komunitas suku bangsa lainnya. Hal ini memperkuat sifat dan karakter sosial masyarakat yang berbasis kemajemukan sosial dan budaya. Konsekuensi dari eksistensi masyarakat yang majemuk ini adalah mencari upaya pengenalan identitas sosial, yang pada masyarakat homogen tidak menjadi tantangan besar untuk mengenalinya.

Pada masyarakat yang majemuk, perbedaan sosial tidak dapat dihindari, selain juga tradisi gaya hidup yang juga mencerminkan identitas masing-masing akan memperkuat perbedaan tersebut. Woodward (1997) berpendapat bahwa identitas dan perbedaan adalah dua sisi yang tidak terpisahkan dari satu pembicaraan tentang masyarakat yang berkembang heterogen sampai dengan majemuk dewasa ini baik di tingkat nasional maupun tingkat global.

Identitas menjadi penting dikenali melalui upaya rekonstruksi sosial dari kondisi sosial yang berbeda secara budaya. Upaya ini dilakukan melalui pemahaman satu istilah yaitu lingkaran budaya (circuit of culture) (Woodward, 1997: 2). Sirkuit budaya adalah suatu interaksi konseptual antara produksi, konsumsi, representasi dan aturan sosial untuk melahirkan identitas yang mencau kepada lingkup budaya tertentu (lihat Woodward, 1997:2). Dengan kata lain, suatu identitas dihasilkan, dipergunakan dan diatur dalam kebudayaan. Dalam masyarakat yang berbeda secara budaya, identitas bersifat relasional dan diungkapkan dalam penandaan yang simbolik saat interaksi budaya yang berbeda tersebut terjadi. Dalam masyarakat yang berbeda, identitas sosial tidak harus disatukan untuk melahirkan satu identitas, melainkan identitas dari sukubangsa yang berbeda dibiarkan berada dalam keanekaragaman identitasnya masing-masing. Hal ini dikarenakan penyatuan identitas akan berhadapan dengan perbedaan yang sangat kontradiktif, yang tidak mudah disatukan. Tantangan yang mungkin dihadapi adalah konflik sosial. Bagi Sumatera Barat, meskipun secara menyeluruh tidak ada upaya penyatuan identitas yang direkayasa dan direncanakan oleh masyarakat maupun pemerintah, namun terdapat upaya penggabungan, bukan asimilasi, dari beberapa budaya suku bangsa dalam suatu tradisi yang berlangsung di Sumatera Barat. Tradisi ronggeng pasaman, misalnya, adalah suatu potret budaya gabungan antara budaya Jawa dan Minangkabau.

Karakter masyarakat Sumatera Barat yang majemuk membutuhkan identifikasi keberadaan kelompokkelompok sosial yang membangun perbedaan nilai budaya, norma sosial dan gaya hidup. Identifikasi nilai budaya ini memerlukan pengenalan lebih jauh dari budaya suku suku bangsa yang ada di Sumatera Barat. Nilai budaya dominan adalah Minangkabau, yang diungkapkan dalam berbagai tradisi kehidupan. Adagium adat basandi syarak, syarak basandi kitabullah, dapat mewakili orientasi nilai budaya pada kehidupan orang Minangkabau, yakni berbasis kepada adat dan agama. Norma sosial di Sumatera Barat pun mengacu kepada norma umum yang berlaku dalam lingkaran budaya Minangkabau. Sementara gaya hidup yang berlangsung di Sumatera Barat lebih dinamis eksistensinya, oleh karena hal ini menyangkut kebiasaan hidup yang kontemporer dan dipegaruhi oleh faktor globalisasi dan produk teknologi komunikasi.

Karakter masyarakat Sumatera Barat berkait dengan upaya mengenali identitas sosial yang tumbuh dalam suasana perbedaan, lebih dapat dideteksi pada konteks kehidupan perkotaan. Beberapa kota dan kabupaten di Sumatera Barat, berdasarkan pengamatan, cenderung memiliki dinamika pemunculan 
identitas baru, seperti di kota Padang, Bukittinggi, Dharmasraya dan Pasaman. Keempat wilayah ini memiliki tingkat kemajemukan yang lebih tinggi dari kotakota dan kabupaten lainnya di Sumatera Barat. Kota Padang, sebagai ibukota provinsi, merupakan wilayah yang paling kentara menjalani heterogenitas sosial. Identitas mayoritas masih dikendalikan oleh budaya Minangkabau, sementara identitas minoritas berasal dari berbagai kelompok migran yang datang dari beberapa suku bangsa yang ada di Indonesia. Di Padang terdapat himpunan kerukunan keluarga yang berbeda asal suku bangsa seperti Kerukunan Keluarga Kerinci, ${ }^{3}$ Kerukunan Keluarga Cina (HBT dan HTT), kerukunan Keluarga Sunda dikenal dengan Perkumpulan Warga Sunda (PWS), Perkumpulan Keluarga Jawa, ${ }^{4}$ dsb.

Berdasarkan realitas sosial yang bervariasi secara kultural di wilayah Sumatera Barat ini, maka pemenuhan karakter masyarakat berbasis kepada satu identitas budaya menjadi tidak masuk akal. Oleh karena itu, Sumatera Barat dapat dikatakan sebagai suatu wilayah budaya yang telah bergeser kepada gambaran identitas masyarakat budaya yang heterogen kepada yang berskala majemuk. Perbedaan tradisi dari para penduduknya yang berbeda secara budaya perlu diberi jalan untuk ditumbuh kembangkan dan diberi kesempatan untuk tetap eksis. Beberapa konsekuensi kemajemukan yang terimplementasi dalam kehidupam masyarakat adalah

(1) Rukun warga

(2) SDM lembaga pemerintahan dan sistem kepemimpinan

(3) Bidang ekonomi, khususnya jaringan bisnis dan pelaku bisnis.

(4) Akses pendidikan

\footnotetext{
${ }^{3}$ Himpinan Keluarga Kerinci di Padang tercatat berjumlah sekitar 30 ribu orang yang terdiri dari keturunan Minang Kerinci, JAwa Kerinci dan Cina Kerinci (http://padangtime.com/read-729)

${ }^{4}$ Persatuan Jawatimuran, adalah persatuan perantau Jawa yang berada di Bukittinggi.
}

\section{Kemajemukan Kearifan Lokal}

$\mathrm{T}$ ipikal masyarakat yang majemuk adalah variasi prinsip dan pandangan hidup, yang dapat dipahami dari konsep kearifan lokal. Kearifan lokal (local wisdom) merupakan istilah yang hangat dibicarakan (buzzword) dan yang sering diketengahkan oleh banyak kalangan mulai dari rakyat biasa sampai dengan pemerintah akhirakhir ini. Kata local wisdom ini sendiri sebenarnya muncul dari persoalan kepedulian masyarakat terhadap kerusakan lingkungan yang diakibatkan oleh dampak industrialisasi yang cenderung eksploitatif. Kemunculannya juga berawal dari kegagalan diplomasi politik ketika berhadapan dengan kekuatan ekonomi pasar bebas dan kapitalisme ekonomi global. Hal lain adalah juga karena local wisdom menjadi penting setelah terjadi ketidakseimbangan berpikir dalam pengelolaan konflik sosial, antara pendekatan represif militer dan diplomasi politik yang cenderung mekanistis. Oleh karena itu, pendekatan kultural adalah salah satu yang dipakai untuk penyelesaian tersebut, dan kearifan lokal dibangkitkan sebagai model dan solusi alternatif yang penting.

Kearifan lokal menjadi penting untuk mempertahankan karakter, baik pada tingkat individu maupun kelompok. Keberadaan kearifan lokal dapat diamati pada beberapa konteks, yaitu:

1. Interaksi antar kelompok.

2. Penguatan tradisi suku bangsa

3. Identitas kelompok

Pertama, di konteks interaksi sosial, masyarakat heterogen mengalami tantangan besar yaitu konflik sosial horizontal. Hal ini terjadi oleh karena terdapat potensi penyebab konflik pada bidang komunikasi, pemahaman makna interaksi simbolik, dan media penyaluran pendapat. Posisi kearifan lokal menjadi penting dalam hal pemanfaatan nilai-nilai budaya universal untuk suatu integrasi sosial. Salah satu kearifan lokal dari perbedaan budaya adalah nilai penyesuaian diri yang diungkapkan dalam istilah "dimana bumi dipijak, disitu langit di junjung". Kearifan lokal lain adalah penghargaan terhadap orang lain yang berbeda budaya, seperti kasus pemberian 
gelar "Abah" dari perkumpulan warga Sunda Sumatera Barat kepada gubernur Irwan Prayitno beberapa waktu lalu. Pemberian gelar "sako" dari orang Minangkabau kepada tokoh-tokoh politik penting negara ini mulai dari pengusaha sampai kepada presiden. Model penghargaan terhadap orang lain yang berbeda secara budaya adalah bentuk dari penghargaan sosial dalam membina interaksi sosial yang harmonis.

Kedua, kearifan lokal dalam konteks masyarakat heterogen semakin dibutuhkan untuk dapat melindungi dan meneguhkan tradisi suku bangsa yang cenderung semakin memudar dari waktu ke waktu akibat penetrasi gaya hidup global yang cenderung bebas nilai. Dampak terbesar dari gaya hidup global ini adalah pemunculan tradisi yang tidak lagi memperhatikan kepatutan, kelayakan dan alur nilai luhur dari budaya suku bangsa. Kehadiran gaya hidup hedonis materialis yaitu penciptaan suasana kehidupan yang sangat ekstrim yang mengkultuskan kenikmatan dan kesenangan hidup berdasarkan pemilikan atau pemanfaatan benda-benda, semakin lama semakin deras masuk ke kehidupan harian anggota masyarakat, tak peduli asal suku bangsa dan budaya mereka. Hedonisme yang sudah menjadi pola pikir sebagian anggota masyarakat dewasa ini, sebenarnya adalah suatu aliran pemikiran filsafat yang menganggap penting kesenangan (the pursuit of pleasure; sensual selfindulgence) dalam kehidupan untuk menghilangkan penderitaan. Perilaku hedonis berarti mencari kesenangan dengan cara apapun baik benda maupun non benda. Hedonis materialis artinya benda-benda yang dimiliki tidak utamanya dianggap produk budaya, melainkan sebagai teman kehidupan yang sangat penting, dan bahkan tergantung terhadapnya untuk mencapai kesenangan pribadi yang sering keluar dari kearifan lokal yang ada. Dalam pengertian ini, penguatan tradisi suku bangsa mengalami tantangan dengan kehadiran gaya hidup hedonis. Untuk itu kearifan lokal menjadi sangat penting dan strategis untuk menangkal serangan gaya hidup hedonis ini. Salah satu tradisi yang bersumber dari kearifan lokal yang dapat dipergunakan untuk menangkal hedonisme dalam masyarakat Minangkabau adalah kesenian, baik dalam bentuk tarian, nyanyian rakyat (folksong), atau baju tradisional. Mempertahankan tradisi adalah melanggengkan nilai dan norma budaya sebagai wujud dari budaya tidak benda (intangible culture). Penguatan tadisi bagi masyarakat Minangkabau dapat disimak pada pepatah berikut:

Kampuang bapaga jo pusako

Nagari bapaga jo undang

Di sinan buek nan balaku

Barieh nan tahan tiliek

Balabeh nan tahan cubo

(Amir, M.S., 1999: 88).

Ketiga, kearifan lokal penting untuk mengatasi krisis identitas kelompok, akibat perilaku individu yang semakin mengarah kepada kepentingan pribadi dan keluar dari aturan dan norma yang sudah disepakati dalam kelompok sosialnya. Prinsip dan aturan yang dibangun secara kolektif berfungsi sebagai pembeda identitas diri terhadap kelompok lain. Pada pengertian ini, kearifan lokal dipahami sebagai sumber prinsip dan aturan yang sesuai dengan perilaku dan kebutuhan anggota kelompok. Salah satu bentuk kearifan lokal yang digunakan untuk identitas kelompok adalah solidaritas dan rasa saling percaya di dalam mewujudkan perilaku kelompok. Hal ini diungkapkan dalam prinsip:

"nan bana kato saiyo

Nan rajo kato mufakat

Elok kato dalam mufakat

Buruak kato di luar mufakat

Dicari rundiang nan saiyoldicari kato nan sabuah

Baiyo-iyo jo nan ketek

Batido-tido jo nan tuo"

Pepatah ini dapat ditafsirkan bahwa solidaritas dan saling percaya dalam kelompok, baik pada satu generasi maupun antar generasi, memberikan kekuatan untuk mempertahankan identitas kelompok. Identitas kelompok ini sangat penting untuk kekuatan kelompok saat berhadapan dengan kelompok lain yang berbeda identitasnya. Dengan kata lain, kearifan lokal mempertahankan diri, bukan melalui perjuangan individual yang ekstrim, 
tetapi melalui pertahanan solidaritas kelompok.

Pepatah Minangkabau menyatakan:

Nan barek samo dipikue

Nan ringan samo dijinjiang

Ka bukik samo mandaki

Ka lurah samo manurun

Nan ado samo dimakan

Nan indak samo dicari.

Dalam konteks masyarakat modern sekarang ini, individualisme dianggap strategi paling jitu untuk mempertahankan diri, sementara kepedulian kepada orang lain dalam satu kelompok semakin memudar. Untuk menghadapi kompetisi masyarakat global, prinsip kebersamaan sudah menjadi suatu kearifan lokal yang patut dijemput kembali untuk diterapkan dalam kehidupan seharihari.

\section{Pembahasan: Kearifan lokal dan Karakter Masyarakat}

$\mathrm{K}$ earifan lokal dapat membantu mempertahankan karakter budaya yang telah dimiliki oleh suatu komunitas. Karakter dapat dipahami sebagai kualitas sifat mental atau moral yang membuat seorang individu atau sekelompok individu berbeda dengan individu atau kelompok individu lainnya. Lokus memahami dan mendetekasi karakter adalah kepada relung psikologis. Dengan demikian, proses membentuk dan mengembangkan karakter adalah pada perkembangan dan kondisi psikologis dari manusia. Pengalaman individu, kondisi psikologis dan lingkungan sosial merupakan rangkaian proses yang berkontribusi kepada pembentukan karakter.

$$
\text { Membicarakan karakter }
$$

masyarakat Sumatera Barat berarti membicarakan karakter masyarakat yang heterogen, meskipun karakter tersebut dapat saja didominasi dari sumber kebudayaan Minangkabau yang dominan. Beberapa karakter yang bersumber dari kearifan lokal yang dapat dicermati dalam masyarakat adalah:
1. Ramah lingkungan. Karakter untuk menjaga lingkungan tetap lestari masih dijalankan oleh sebagian besar masyarakat, terutama masyarakat di sekitar hutan dan pegunungan. Untuk memperkuat karakter tersebut dipraktekkan tradisi pantangan "larangan", seperti yang dikenal dengan istilah ikan larangan, hutan larangan ataupun kebun larangan.

2. Adab berkomunikasi. Ini adalah karakter yang memperhatikan tingkat generasi, usia, dan status sosial. Dalam praktek, terutama yang dilaksanakan di kalangan masyarakat desa/nagari, anggota masyarakat menggunakan sebutan dan panggilan untuk membangun komunikasi yang beradab, bersopan santun dan saling menghormati.

3. Karakter Pemimpin. Karakter ini terutama terungkap pada komunitas adat yang sangat kental memperhatikan posisi asal usul dalam garis genealogis kaum dan suku. Pengormatan kepada pemimpin dipandang sebagai karakter asli yang mengedepankan kearifan lokal untuk mempertahankan struktur kepemimpinan masyarakat. Dalam budaya Minangkabau, seorang pemimpin disebut dengan "didahulukan selangkah dan ditinggikan serantiang".

4. Penghormatan kepada Perempuan. Karakter ini sangat kental dalam tradisi matrilineal. Perempuan bagi masyarakat dianggap sangat mulia dan mendapatkan tempat terhormat di dalam sistem kekerabatan mulai dari tingkat keluarga inti, keluarga luas sampai kepada tingkat suku. Penghormatan kepada posisi dan peran perempuan dalam masyarakat ternyata memberikan kekuatan penyeimbang di dalam proses pengambilan keputusan dalam suatu rapat adat. Keberadaan perempuan di dalam proses politik, juga diakui sebagai suatu keistimewaan dalam konteks politik modern. Di Indonesia, kuota $30 \%$ dalam parlemen yang diisi oleh wanita, adalah suatu bukti kearifan lokal sudah diterapkan dalam tata pemerintahan modern. 
5. Keadilan sosial. Karakter keadilan sosial dalam kehidupan masyarakat Sumatera Barat diibaratkan sebagai suatu keseimbangan alamiah antara kelompok dalam suatu masyarakat. Tidak ada rumus pasti dan matematis di dalam membangun suatu keadilan sosial. Hal ini seperti dinyatakan dalam pepatah: mandapek samo balabo; kahilangan samo marugi;maukua samo panjang; mambilai samo laweh; baragieh samo banyak; manimbang samo barek.

6. Berbagi peran dan kedudukan. Secara tradisional, masyarakat Sumatera Barat telah diajarkan untuk menempatkan peran dan status sesuai yang didapat dan diusahakan. Dalam konteks dewasa ini, kontestasi sosial sering membuahkan korban yakni hilangnya hak dan kewajiban orang lain oleh karena kesalahan dalam mengambil peran dan posisi. Untuk menghindari kesalahan status dan peran, kearifan lokal tentang kesesuaian status dan peran seseorang telah di nyatakan sebagai berikut: Manumbuak di lasing; batanak di pariuak; jawi malanguah; kambiang mambebek.

"Nan Buto pahambuih lasuang

Nan pakak palapeh badie

Nan patah panghuni ayam

Nan binguang ka disuruah-suruah

Nan buruak palawan karajo

Nan kuek paangkuik baban

Nan jangkuang jadi panjuluak

Nan randah panyaruduak

Nan pandai tampek batanyo

Nan cadiak bakeh baiyo

Nan kayo tampek batenggang

7. Alam terkembang dijadikan guru. Ini adalah prinsip hidup yang sangat mendalam bagi masyarakat Sumatera Barat, khususnya orang Minangkabau. Prinsip ini mengajarkan suatu kearifan lokal yang sangat jitu untuk menghadapi setiap situasi dan kondisi dalam kehidupan. Amir MS (1977:99) mengungkapkan beberapa sifat yang dihasilkan dari kearifan memperhatikan apa yang dipersembahkan oleh alam kepada manusia, yaitu:

a. Sikap waspada: "dalam awa akhie mambayang; dalam baiak kanalah buruak; dalam galak tangih kok tibo; hati gadang hutang kok tumbuah"

b. Sikap prediksi:

"alun rabah lah kaujung; alun pail ah babaliak; alun dibali lah bajua; alun dimakan lah taraso"

c. Sikap cermat:

"dihawai sahabih raso; dikaruak sahabih gaung"

d. Sikap prioritas:

"mangaji dari alif; babilang dari aso"

e. Sikap rasional/masuk akal dan dapat dipertanggungjawabkan:

" Mancancang balandasan; malompek basitumpu.

\section{E. Kesimpulan}

$\mathrm{K}$ arakter masyarakat Sumatera Barat telah bergerak dinamis dari tipe masyarakat yang heterogen kepada tipe masyarakat yang majemuk. Kehadiran berbagai anggota masyarakat yang berasal dari sejumlah suku bangsa lain telah mewarnai mozaik sosial di provinsi ini. Kondisi sosial serupa ini menimbulkan perubahan sosial yang sangat jelas kentara. Akibat perubahan ini adalah berupa krisis identitas sosial, melalui penurunan kekuatan anggota masyarakat di dalam mempertahankan norma dan nilai budaya masing-masing. Selain karena pengaruh interaksi sosial dari kelompok sosial yang berbeda suku bangsa, penurunan kekuatan ini juga karena masuknya gaya hidup global. Tantangan terhadap krisis identitas sosial menjadi agenda sosial yang penting bagi semua pihak yang berkepentingan di provinsi ini untuk kembali menguatkan karakter sosial yang telah ada yang bersumber dari norma dan nilai budaya dari suku-suku bangsa.

Wujud sumber norma dan nilai budaya suku bangsa yang penting adalah kearifan lokal. Wujud ini dapat dikatakan sebagai prinsip atau pedoman yang tersembunyi dan melekat pada cara berpikir anggota masyarakat suatu suku bangsa. Kearifan lokal agaknya menjadi alternatif utama dari derasnya krisis indentitas dan karakter sosial masyarakat di provinsi Sumatera Barat ini. Untuk dapat mengedepankan kearifan lokal dipakai dalam membangun pola interaksi sosial 
yang harmonis dari masyarakat heterogen di Sumatera Barat, maka upaya menggali dan menumbuhkembangkan berbagai jenis kearifan lokal dari masing-masing suku bangsa perlu dilakukan. Salah satu bentuk kearifan lokal yang dimiliki oleh suku bangsa Minangkabau adalah pepatah dan petitih serta adagium sosial yang menjadi pedoman untuk bertingkah laku.

\section{Daftar Pustaka}

Amir M.S. 1997. Adat Minangkabau: Pola dan Tujuan Hidup Orang Minang. Jakarta: PT Mutiara Sumber Widya

Effendi, Nursyirwan (editor). 2010. Bunga Rampai Budaya: Rumah Tradisional, Sistem Pewarisan, Songket Palembang dan Adat Minangkabau. (Kumpulan penulis: Maryetti, Refisrul, Rois Leonard Arios, Ernatip dan Ajisman). Padang: BPSNT Padang Press

Kottak, Conrad Phillip. 2006. Anthropology: The Exploration of Human Diversity. Boston: McGraw Hill Higher Education

Theodorson, George A., and Achilles G. Theodorson. 1969. A Modern Dictionary of Sociology. New York: Barnes and Noble Books

Woodward, Kathryn. 1997. Identity and Difference: Culture, Media and Identities. London: Sage Publication 